2000

\title{
Liberal Internationalism and Policy Discourse about the Asian Economic Crisis
}

Robert Wai

Osgoode Hall Law School of York University, rwai@osgoode.yorku.ca

Follow this and additional works at: http://digitalcommons.osgoode.yorku.ca/all_papers

\section{Repository Citation}

Wai, Robert, "Liberal Internationalism and Policy Discourse about the Asian Economic Crisis" (2000). All Papers. Paper 232.

http://digitalcommons.osgoode.yorku.ca/all_papers/232

This Conference Paper is brought to you for free and open access by the Research Papers, Working Papers, Conference Papers at Osgoode Digital

Commons. It has been accepted for inclusion in All Papers by an authorized administrator of Osgoode Digital Commons. 

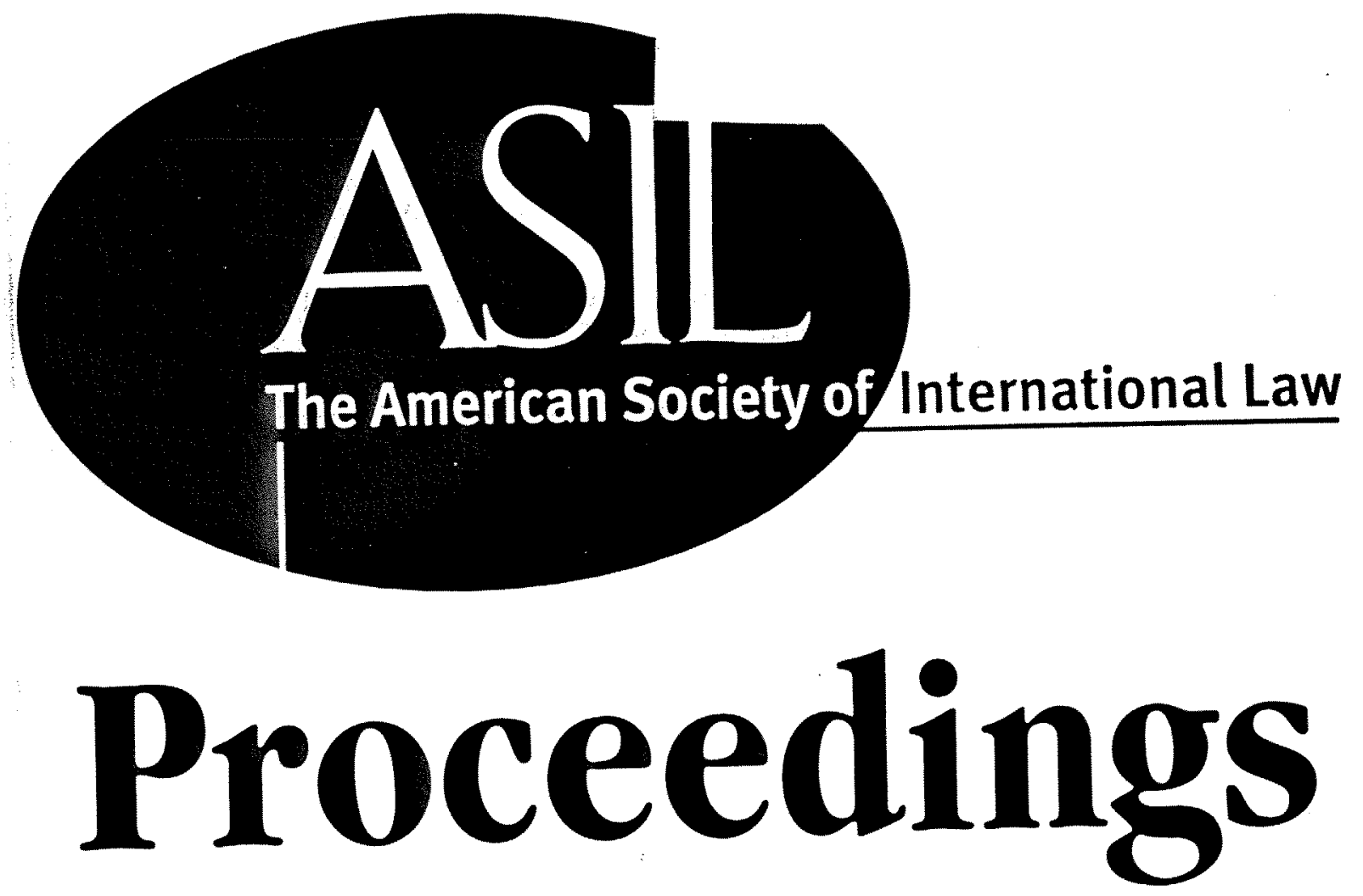
of the
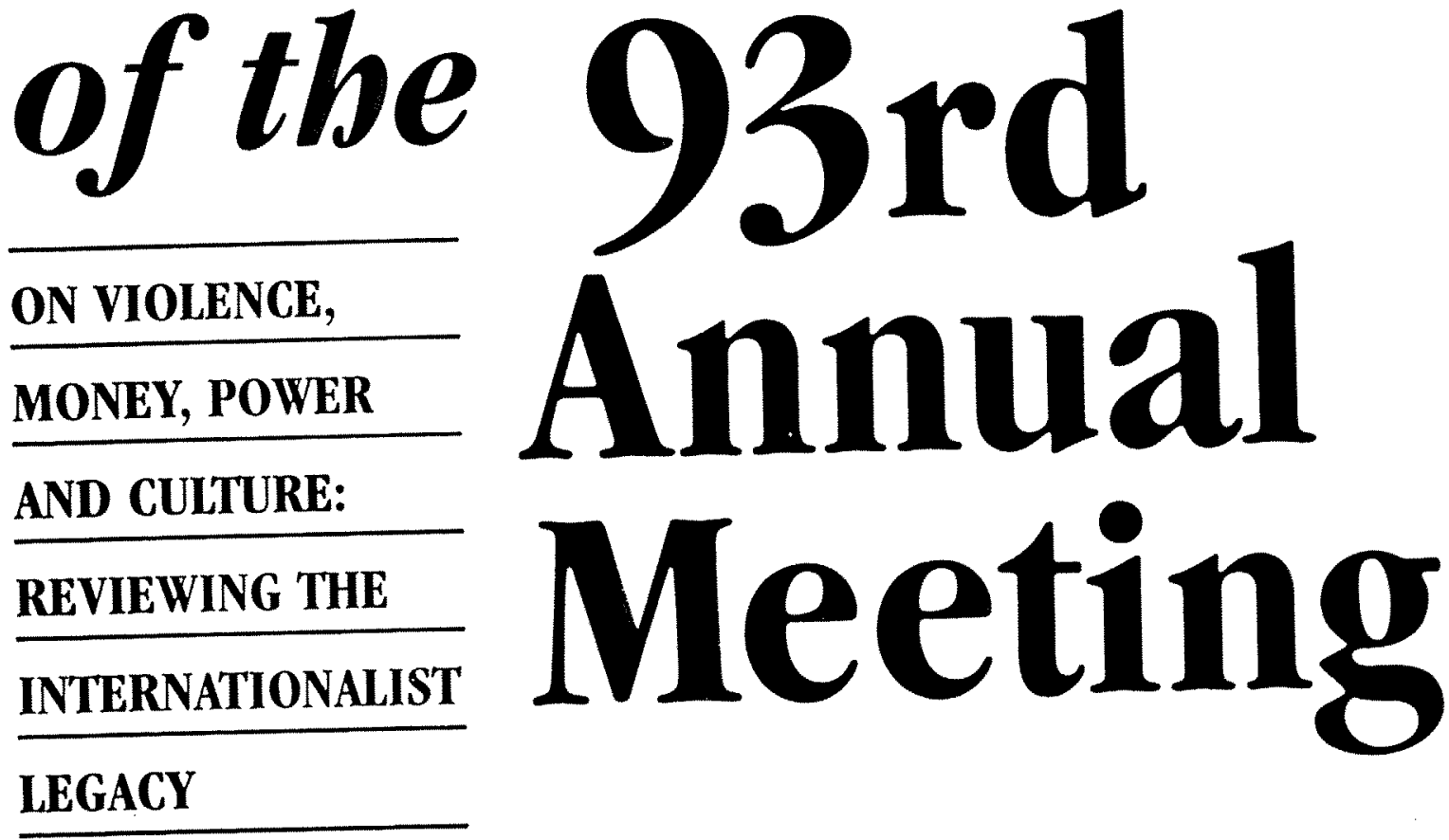

March 24-27, 1999

Washington, D.C. 
Human Rights, Democracy and Free Markets: Is it a Package?

REMARKS BY:

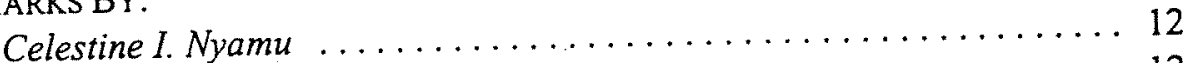

Roberto P. Aponte-Toro ....................... 123

Hunger and Free Trade

REMARKS BY:

Maxwell o. Chibundu ........................ 126

Peter J. Matlon . . . ........................ 127

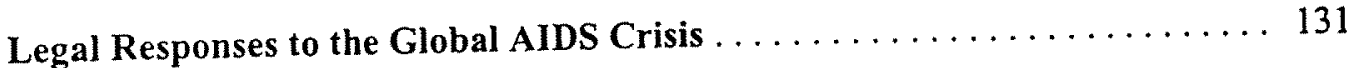

Pacific Chaos and the Debtor Nation, 1990s Style

Comparing the "1990s-Style" and "1980s-Style" Debt Crises

Competing Explanations for the Asian Crisis and Consequences of the Crisis for the Asian Development Model

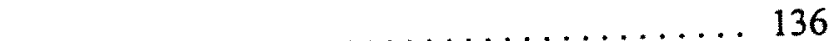

Liberal Internationalism and Policy Discourse About the Asian Economic Crisis

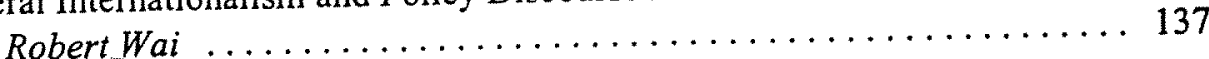

REMARKS BY:

Spencer Weber Waller . . . . . . . . . . . . . . . . . 138

Race, Riots and Money: The Role of the Bretton Woods Institutions in the Indonesian Financial Crisis

REMARKS BY:

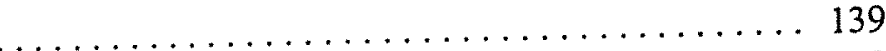

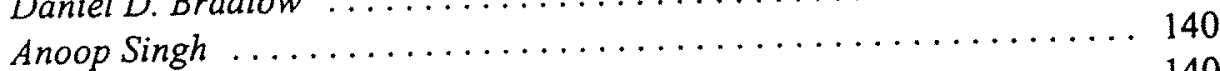

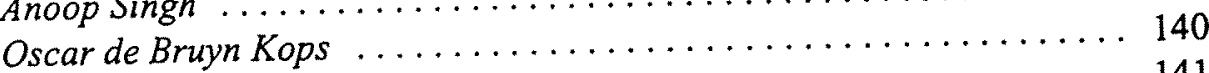

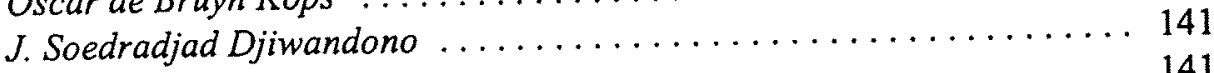

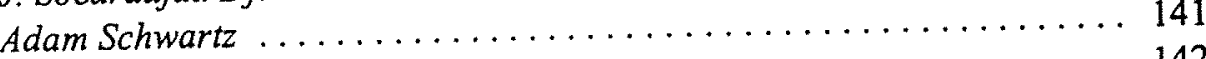

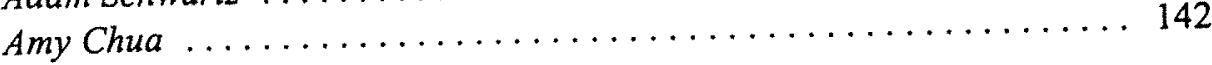

Social and Labor Issues and the Agendas of the IMF, World Bank, WTO and OECD

REMARKS BY:

Virginia Leary $\ldots \ldots \ldots \ldots \ldots \ldots \ldots$

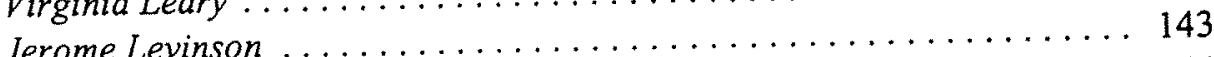

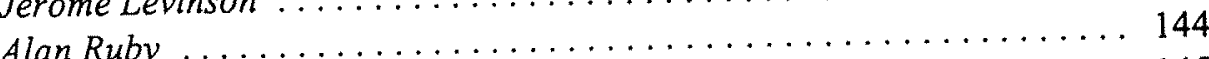

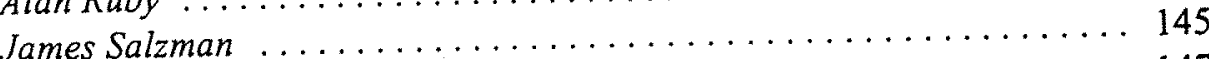

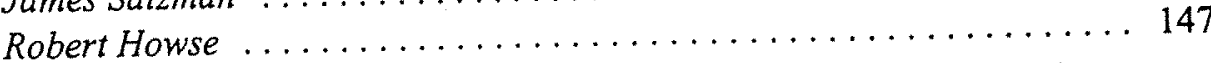

UN Fiscal Crisis Brought on by U.S. Arrears

REMARKS BY:

John Knox $\ldots \ldots \ldots \ldots \ldots \ldots \ldots \ldots$

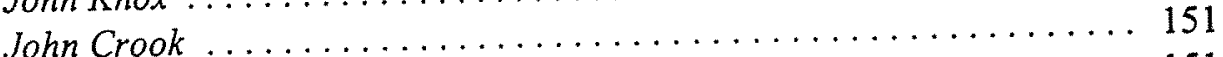

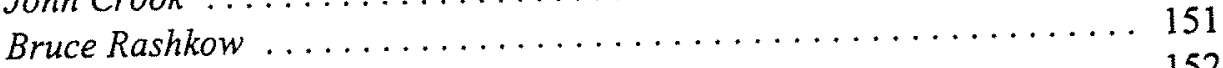

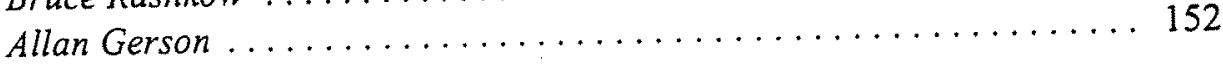

POWER

\section{LECTURES}

The University of Iowa Center for International Finance and Development: Using Cyberspace to Promote Social Justice 


\title{
LIBERAL INTERNATIONALISM AND POLICY DISCOURSE ABOUT THE ASIAN ECONOMIC CRISIS
}

\author{
by Robert Wai*
}

The Asian crisis presents an opportunity to examine the policy discourse of international financial institutions in relation to one theme of this year's Annual Meeting, namely the liberal cosmopolitan tradition in international law.

The connection between the policy of international financial institutions (IFIs) and liberal internationalism can be explored through a review of the efforts of nineteenth-century liberal thinkers such as John Stuart Mill to develop analytical frameworks for addressing relations among sovereign states and relations of empire. The solution in both domains was to appeal to the ideal of mutually beneficial cooperation. Liberals emphasized how a basic harmony of interests could be realized among "civilized" states through policies of nonintervention and free trade. Between civilized and "barbarian" states, interventionist imperial relations would provide the colony with economic and political development in exchange for resources, labor, markets and destinations for surplus population. The appeal to the goal of mutual benefit-a kind of Pareto optimality between societies-combined normative appeal with pragmatic realism.

The discussion of policy alternatives by IFIs such as the IMF and the World Bank continues to be patterned by the liberal ideal of cooperative benefit as the acceptable frame for public justification. On the one hand, aspects of the formal structure of the IFIs, such as weighted voting, as well as the effective influence of dominant states such as the United States over decisions and policy models, show how IFIs reflect the realist need to recognize the power of the powerful. On the other hand, the work of these institutions must be justified as beneficial to less powerful economies.

A series of familiar, crosscutting, liberal distinctions are used to distinguish the domain of the mutually beneficial from that of the politically controversial. First, the legal is distinguished from the nonlegal. For example, constituting agreements, such as the IMF Articles of Agreement, are argued to limit the mandate of IFIs to undertake many kinds of policies. A second distinction is made between economic policy, such as monetary or fiscal policy, and social policy or politics. The obvious difficulty with both of these distinctions is that legal boundaries are often unclear and distinctions between spheres of economic policy and social policy clearly interconnect with and impact upon each other. The IMF effectively acknowledged this linkage when it advocated structural adjustment policies in response to the 1982 debt crisis.

A third distinction, which often aligns with the first two, is that between the international and the domestic. Economic policy for developing countries is thought to be appropriately guided by international institutions and the international market, while responsibility for social policies such as distribution is left to the domestic choices of national governments. Recently, 
a fourth kind of classification has emerged in IFI discourse, in which "good governance" policies are distinguished from harmful government intervention and corruption.

Such distinctions are porous, and are deployed differently across time and issues. Nonetheless, the distinctions do constrain the kinds of policy prescriptions made by IFIs. For example, the search for mutual benefit rules out substantial international redistribution to overcome the legacies of empire. This deeper criticism aside, constraints on policy discourse may be counterproductive even within the narrower domain of mutually beneficial policy if categories that were adopted for the purpose of justification and legitimation are believed to be empirically accurate descriptions of the state of the world. The unfolding of the Asian economic crisis demonstrated the danger of underappreciating social contexts and linkage among issues and sectors. IFI prescriptions for adjustment underestimated the delicate balances among economic conditions, ethnic conflict and political oppression. Prescriptions against state intervention and state-business "cronyism" ignored the potential public benefits of government involvement and leverage over the private sector.

The use of classifications also deflects responsibility for difficult problems from IFIs to other actors, in particular national governments. IFIs attribute the economic crisis to domestic corruption and excessive government intervention rather than allocate appropriate causal significance to international currency markets and the deregulation recommended by international institutions such as themselves. Such deflection of responsibility, besides being normatively questionable, delegitimizes the IFIs as concerned mainly with Western interests or ideological convictions. Such attribution of responsibility also feeds into ethnic and civilizational discourse evident, for example, in the widespread use of the label "Asian flu." This unfortunate metaphor associates the origins of the Asian economic crisis with corrupt or authoritarian practices in Asia, with the economic effects sweeping across the region to infect the healthy parts of international society. Confusion of accountability and in analysis can be lessened by a healthy skepticism toward the strong distinctions of liberal internationalism. 